\title{
Inter-Simple Sequence Repeat (ISSR) Markers to Study Genetic Diversity Among Cotton Cultivars in Associated with Salt Tolerance
}

\author{
Ali Akbar ABDI ${ }^{1}$, Omid SOFALIAN ${ }^{1 *}$, Ali ASGHARI', Majid SHOKRPOUR ${ }^{3}$, \\ Hedayat BAQHERI ${ }^{2}$, Seyed Yaqhoub SEYYED MASOUMI ${ }^{4}$ \\ ${ }^{1}$ University of Mohaghegh ardabili, Faculty of Agricultural Science, Plant breeding Department, \\ Aradabil, 179, Iran; Sofalian@uma.ac.ir (*correspondingauthor) \\ ${ }^{2}$ Bu Ali Sina University, Faculty of Agriculture, Plant breeding Department, Hamedan, Iran \\ ${ }^{3}$ Tehran University, Faculty of Agriculture and Natural Resources, Department of Horticulture, Tehran, Iran \\ ${ }^{4}$ Moghan agro-industry institute, Ardabil, Iran
}

\begin{abstract}
Developing salt-tolerant crops is very important as a significant proportion of cultivated land is salt-affected. Screening and selection of salt tolerant genotypes of cotton using DNA molecular markers not only introduce tolerant cultivars useful for hybridization and breeding programs but also detect DNA regions involved in mechanism of salinity tolerance. To study this, 28 cotton cultivars, including 8 Iranian cotton varieties were grown in pots under greenhouse condition and three salt treatments were imposed with salt solutions $(0$, 70 and $140 \mathrm{mM} \mathrm{NaCl}$ ). Eight agronomic traits including root length, root fresh weight, root dry weight, chlorophyll and fluorescence index, $\mathrm{K}^{+}$and $\mathrm{Na}^{+}$contents in shoot (above ground biomass), and $\mathrm{K}^{+} / \mathrm{Na}^{+}$ratio were measured. Cluster analysis of cultivars based on measured agronomic traits, showed 'Cindose' and 'Ciacra' as the most tolerant cultivars, and 'B-557' and '43347' as the most sensitive cultivars of salt damage. A total of 65 polymorphic DNA fragments were generated at 14 inter-simple sequence repeat (ISSR) loci. Plants of 28 cultivars of cotton grouped into three clusters based on ISSR markers. Regression analysis of markers in relation with traits data showed that 23, 33 and 30 markers associated with the measured traits in three salt treatments respectively. These markers might help breeders in any marker assisted selection program in order to improving cotton cultivars against salt stress.
\end{abstract}

Keywords: cotton, genetic variation, salt tolerant, ISSR marker

\section{Introduction}

Cotton is one of the most economically important crops which is cultivated for about 85 years in Iran, mostly on irrigated lands (according to report of Iran Cotton Union). Gossypium herbaceum and G. hirsutum are mostly cultivated species in Iran.

One of the major abiotic stresses responsible for low yield in arid and semi-arid regions of the world is soil salinity which according to the FAO (2008), Land and Plant Nutrition Management Service affects about 20 percent of irrigated agriculture. About 90 percent of Iran cultivation area falls in arid climate where no crops can be grown without irrigation. Half of the irrigated agriculture is influenced by soil salinity which causes more than 50 percent yield reduction in arid regions of Iran. More than 7.6 milliard cubic meters of salt water is flowing annually in 12 rivers of Iran (Qureshi et al., 2007).

Cotton is relatively a salt tolerant crop. Most of the cotton cultivars and germplasms could withstand salinity levels of 7 to $8 \mathrm{ds} / \mathrm{m}$ (deci Simens per meter) without significant reduction in growth and yield. Early seedling stage is more sensitive to saline condition than later stages of growth. However there is variation exists for salt tolerance. $G$. herbaceum and $G$. barbadense were found to be more tolerant than $G$. arboreum and $G$. hirsutum (CICR Technical Bulletin No: 2). Asiatic cotton is more tolerant than upland cotton to salinity. Salt tolerance is a quantitative trait which is affected by the environmental factors. However, selection based on genetic rather than phenotypic characteristics (marker assisted selection; MAS) is a fast, reliable and cost effective approach which can enhance the identification of tolerant cotton genotypes. Inter-simple sequence repeat (ISSR) fingerprinting is a PCR based method was developed such that no prior sequence knowledge was required. 16-25 bp long microsatellites such as (GACA) ${ }_{4}$ are used as primers to amplify the intersimple sequence repeats of different sizes (Pradeep et al., 2002). This technique has proven to be a simple, quick and inexpensive method which can generate high percentages of polymorphic loci. In cotton knowledge of molecular markers is very limited due to the several factors reviewed by Preetha and Raveendren (2008). Lack of a high density molecular map and a polymorphism detection methods 
are most important factors. ISSR technique reported as an easy and informative genetic marker system for revealing both inter and intraspecific variations in cotton (Liu and Wendel, 2001), yielding a multi locus marker system useful for fingerprinting, diversity analysis, and genome mapping. In this investigation genetic diversity of 28 cotton cultivars is studied under salt stress conditions, compared with genetic distance estimated from ISSR markers and explained reliable molecular markers of salt tolerance.

\section{Materials and methods}

\section{Plant cultivars and treatments}

Seeds of 28 cultivated varieties of cotton ( $G$. hirsutum) (Tab. 1) were obtained from Moghan agro-industry institute, Ardabil, Iran. Individual plants were grown in three replication in a factorial experiment based on Randomized complete block design. Pots $(37 \times 27 \times 24 \mathrm{~cm})$ placed in a temperature-controlled greenhouse $\left(32^{\circ} \mathrm{C}\right.$ / humidity $60 \%$ ). All pots watered with distilled water first and in five and ten days later three salt treatments of 0,70 , and 140 $\mathrm{mM} \mathrm{NaCl}$ were applied to plants according to Munns et al. (1995).

\section{Morphological and physiological traits}

Three weeks after first salt treatment, at the 6-leaf stage, chlorophyll and fluorescence indexes were measured with Chlorophyll Meter SPAD-502 and Chlorophyll Fluorometer OS-30P respectively. After these measurements aboveground and underground parts were harvested separately. Above-ground part oven- dried at $70^{\circ} \mathrm{C}$ for 48 hours. One gram of dried parts was grinded and heated in an oven at $550^{\circ} \mathrm{C}$. Ten $\mathrm{ml} \mathrm{Hcl}$ was added to dry-grinded material to extract sodium and potassium ions and was adjusted to a final volume of $100 \mathrm{ml}$ with double distilled water. $\mathrm{Na}^{+}$ and $\mathrm{K}^{+}$were determined with the help of flame photometer (Darwish et al., 2007). Freshly harvested roots were washed three times with distilled water to wash off attached minerals and dried on filter paper. Root length and root fresh weight were measured then roots oven- dried at $70^{\circ} \mathrm{C}$ for 48 hours to measure root dry weight. Data analysis was done by SPSS19. For cluster analysis of cultivars, Ward's method based on Euclidean distances was conducted.

\section{DNA extraction and amplification}

Leaf tissues of plants at four-leaf stage were ground to a fine powder in liquid nitrogen and used for DNA extraction by using $\mathrm{CTAB}$ method with minor modifications (Doyle and Doyle, 1990). 34 ISSR primers were supplied from Bioneer Company (South Korea). The PCR reaction volume was 20 ul containing $30 \mathrm{ng}$ genomic DNA, PCR buffer $(2 \mu \mathrm{l})$, dNTP $(0.2 \mu \mathrm{l}), \mathrm{MgCl} 2(0.8 \mu \mathrm{l})$, each primer $(1.6 \mu \mathrm{l})$, and $1 \mathrm{U}$ of Taq DNA polymerase. The temperature cycles were programmed as $94^{\circ} \mathrm{C}$ for $5 \mathrm{~min}$ followed by 35 cycles of 94 for $1 \mathrm{~min}(45-55)^{\circ} \mathrm{C}$ for $1 \mathrm{~min}, 72^{\circ} \mathrm{C}$ for $2 \mathrm{~min}$, and finally $5 \mathrm{~min}$ at $72^{\circ} \mathrm{C}$ for final extension. Amplified products were separated by electrophoresis on 2 percent agarose gels and visualized under UV light. ISSR fragments were scored as present (1) or absent (0).

\section{Marker's data analysis}

Cluster analysis, drawing the cluster produced by UPGMA clustering and principle component analysis was performed using NTSYS 2 Software. GenALEx6.3 was used to calculate Shannon Diversity Index, Marker Index (MI) and Polymorphism Information Content (PIC) and to perform Mantel's test (Liedloff, 1999). PopGene 1.32 software was applied to calculate Nei's gene diversity index. Other statistical analysis to investigate possible relations of molecular markers and measured traits was done by SPSS19.

\section{Results and discussion}

Cluster analysis of 28 cotton commercial studding cultivars based on agronomic traits performed based on WARD method. Three distinct clusters at 0 salt treatment

Tab. 1. Name and origin of the genotypes used

\begin{tabular}{|c|c|c|c|c|c|}
\hline Cultivar Number & Cultivar Name & Origin & Cultivar Number & Cultivar Name & Origin \\
\hline 1 & 'Avangrd' & Bulgaria & 15 & 'Cindose' & Greece \\
\hline 2 & 'Opal' & America & 16 & 'Shirpan 539’ & Bulgaria \\
\hline 3 & 'Oltan' & Iran Trade & 17 & 'Shirpan 603' & Bulgaria \\
\hline 4 & 'B557’ & Pakistan & 18 & 'Mehr' & Iran Trade \\
\hline 5 & 'Bakhtegan' & Iran Trade & 19 & 'Mutazhenez' & Mutant \\
\hline 6 & 'Bolghar 539' & Bulgaria & 20 & 'Nazil'i & Turkey \\
\hline 7 & 'Bolghar 996' & Bulgaria & 21 & 'Varamin' & Iran Trade \\
\hline 8 & 'Beliisovas' & Turkey & 22 & 'Varamin 349' & Iran Trade \\
\hline 9 & 'Tabladika' & Spain & 23 & 'No-200’ & Greece \\
\hline 10 & 'Tashkand' & Uzbekistan & 24 & 'No-228' & Greece \\
\hline 11 & 'Chegurava 15:18’ & Turkey & 25 & ‘010’ & Uzbekistan \\
\hline 12 & 'Khordad' & Iran Trade & 26 & ‘4.S.4’ & Greece \\
\hline 13 & 'Sahel' & Iran Trade & 27 & ‘4325’ & Greece \\
\hline 14 & 'Ciacra' & Iran Trade & 28 & ‘43347’ & Greece \\
\hline
\end{tabular}


122

were indicated (Fig. 1-A). There were significant differences between the means of three clusters $(\alpha=1 \%)$. The mean of first and third cluster showed the lowest and the highest deviations from the total mean respectively (Fig. 2- A). Four clusters identified in $140 \mathrm{mM}$ salt stress treatment (Fig. 1-B) which among them group 1 and 4 showed the lowest and the highest deviations from the total mean respectively (Fig. 1-B and 2-B). Negative deviation of $\mathrm{Na}^{+}$ content and positive deviation of other agronomic studied traits from the total mean was represented a high-yield, salt-tolerant cultivar. 'Cindose' and 'Ciacra' at control salt treatment were in the group of low-yield while at salt shock treatment they showed the highest yield. This means these two cultivars are the most salt- tolerant genotypes. 'B557' and ' 43347 ' are the most salt-sensitive genotypes in the other way around.

\section{ISSR data}

14 ISSR primers from 34 studding ones produced 85 visible bands. Of these, 65 bands were polymorphic and
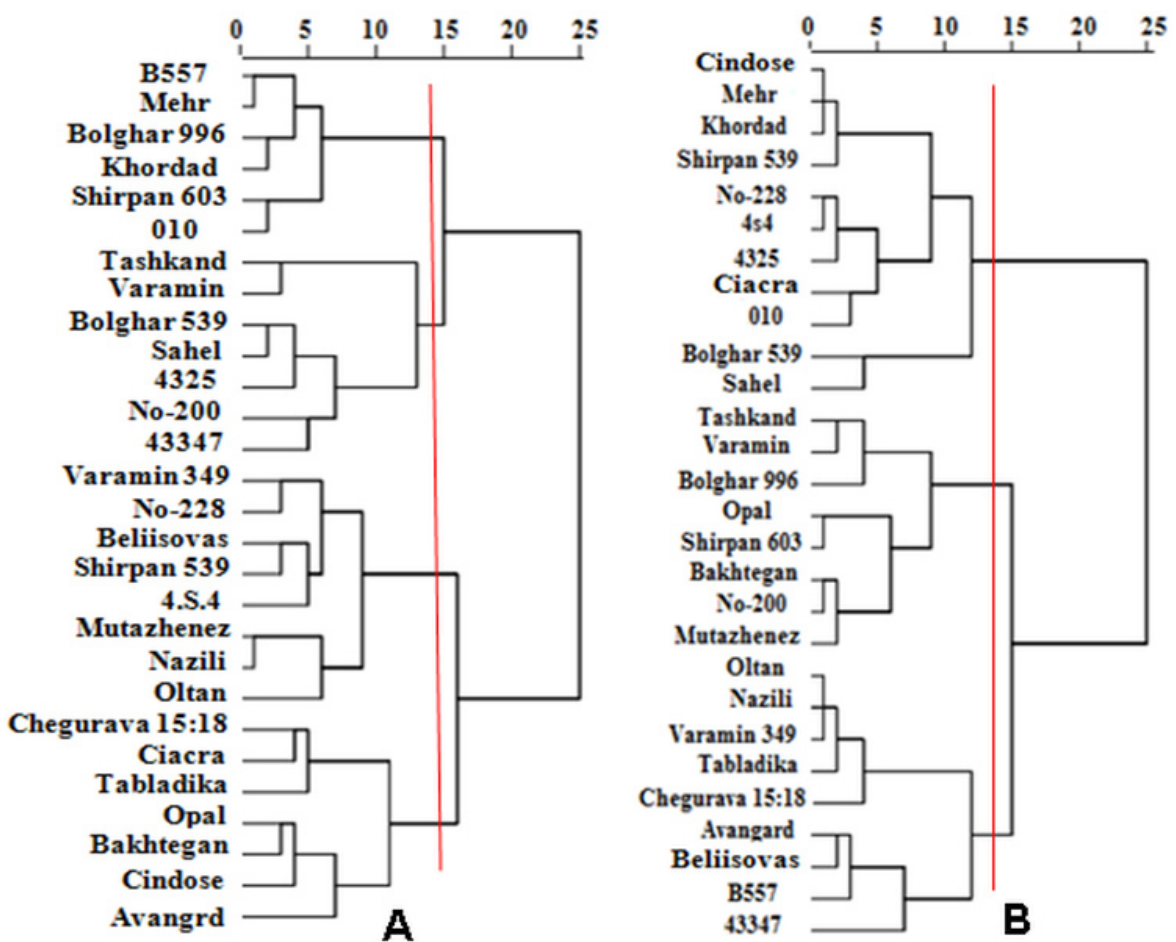

Fig. 1. Cluster analysis dendrogram of 28 cotton commercial cultivars based on agronomic traits (A. Control B. $140 \mathrm{Mm} \mathrm{NaCl}$ )

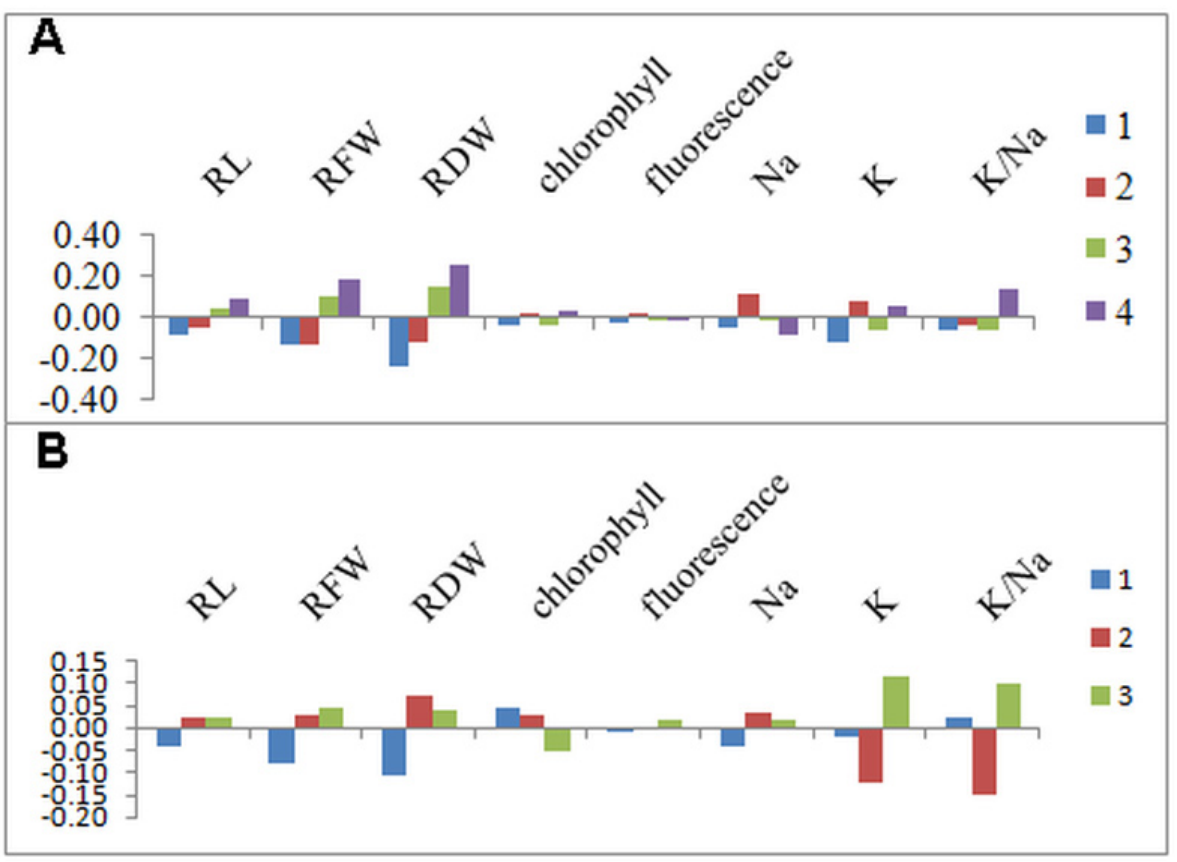

Fig. 2. The average deviation of the mean cluster: A. Control B. $140 \mathrm{mM}$ 
20 bands were monomorphic. Number of polymorphic bands per primer ranged from 3 (ISSR-2 and ISSR-28) to 8 (ISSR-1, ISSR -5, ISSR -8, ISSR- 14 and ISSR 19). Fig. 3 , shows ISSR-19 banding pattern. ISSR-30 and ISSR-9 revealed the highest MI (2.028) and PIC indexes (0.378) respectively (Tab. 2). The marker index is used to evaluate the utility of marker system and is the product of the total number of loci per primer pair and the arithmetic mean heterozygosity (Nei, 1973).The PIC value provides the value of a marker for detecting polymorphism introduced by Botstein et al. (1980). When frequency of two alleles in a population is equal then PIC value gets the heights value of 0.5 (Mateescu et al., 2005).

\section{Estimation of genetic diversity}

Nei's gene diversity index (Nei, 1973) is commonly estimated parameter as a measure of gene diversity. The average Nei's gene diversity index in ISSR data set was 0.299 and ISSR-8 showed the highest value (0.398) (Tab. 2). In Similar study by Sharaf et al. (2009) this index was 0.228, 0.284 and 0.272 respectively for RAPD, ISSR and AFLP markers used.

Cluster analysis based on molecular data was generated by UPGMA using Jaccard's similarity coefficients (Fig.
4). The correlation coefficient was statistically significant $(r=0.84, \alpha=1 \%)$. The cluster analysis of ISSR markers separated the cotton genotypes into three distinct clusters (Fig. 4). First cluster included 18 cultivars: 'Avangard', 'Sahel', 'B557', 'Bakhtegan', 'Khordad', 'Opal', 'Bolghar 996', 'Varamin', 'No-200', 'Varamin 349', 'Cindose', ‘4325', 'Shirpan 539', 'Mehr', 'Tabladika', 'Tashkand', 4.S.4' and '43347'. Two cultivars 010 and Beliisovas clusterd together and the third cluster included 8 remained cultivars.

\section{Molecular data and agronomic traits}

The success of any selection scheme relies on the availability and identification of agronomical beneficial alleles for the target traits. Traditionally, the genetic variability exploited by modern breeding to improve quantitative traits has been derived from highly selected, elite materials with a genetic basis much narrower than that of the wild relatives from which crops were originally domesticated (Tanksley and Nelson, 1996). However, beneficial QTL alleles have also been identified among wild relatives of crops (Tanksley and Nelson, 1996); therefore, the same should also hold true for salt tolerance.

Stepwise regression analysis between molecular data $(0,1)$ as fixed variable and studied agronomic traits data

Tab. 2. Polymorphic and Nei's (1973) gene diversity

\begin{tabular}{|c|c|c|c|c|c|c|c|}
\hline Primers & Primer sequences & $\begin{array}{l}\text { Number of } \\
\text { amplified } \\
\text { bands }\end{array}$ & $\begin{array}{c}\text { Number of } \\
\text { polymorphic } \\
\text { bands }\end{array}$ & $\begin{array}{c}\text { Polymorphic } \\
\text { / amplified } \\
\text { bands }(\%)\end{array}$ & PIC & MI & $\begin{array}{l}\text { Nei's gene } \\
\text { diversity }\end{array}$ \\
\hline ISSR- 1 & 5/ AGAC AGACGC 3/ & 8 & 8 & 100 & 0.189 & 1.512 & 0.189 \\
\hline ISSR-2 & 5/ GACAGACAGACA GACA 3' & 3 & 3 & 100 & 0.225 & 0.675 & 0.223 \\
\hline ISSR- 3 & 5' AGAGAGAGAGAGAGAGC 3/ & 5 & 4 & 80 & 0.101 & 0.404 & 0.100 \\
\hline ISSR- 5 & 5/ AACAACAACGC $3 /$ & 8 & 8 & 100 & 0.115 & 0.920 & 0.151 \\
\hline ISSR- 8 & 5/ GACGACGACGACG 3/ & 8 & 4 & 50 & 0.378 & 1.512 & 0.398 \\
\hline ISSR-9 & 5/ TСТСТСТСТСТСТСТСС 3 ' & 6 & 4 & 66 & 0.376 & 1.504 & 0.390 \\
\hline ISSR- 14 & 5/ CACACACACACAGT 3/ & 8 & 8 & 100 & 0.375 & 3 & 0.393 \\
\hline ISSR- 15 & $5 /$ ACGACGACGACGAAC 3 ' & 6 & 3 & 50 & 0.349 & 1.047 & 0.387 \\
\hline ISSR- 16 & 5 CACACACACACAAG 3 & 5 & 4 & 80 & 0.193 & 0.772 & 0.238 \\
\hline ISSR- 19 & 5/ AGAGAGAGAGAGAGAGT 3/ & 8 & 6 & 75 & 0.338 & 2.028 & 0.358 \\
\hline ISSR- 28 & 5/ GAGGAGGAGGC 3/ & 3 & 1 & 33 & 0.337 & 0.337 & 0.375 \\
\hline ISSR- 30 & 5/ GAGAGAGAGAGAGAGAC 3' & 6 & 5 & 83 & 0.343 & 1.715 & 0.338 \\
\hline ISSR- 31 & 5/ CACCACCACGC 3/ & 6 & 5 & 83 & 0.336 & 1.680 & 0.334 \\
\hline ISSR- 32 & 5 AGAGAGAGAGAGAGAC 3 ' & 5 & 2 & 40 & 0.296 & 0.592 & 0.305 \\
\hline Total & & 85 & 65 & & 3.95 & 17.64 & 4.179 \\
\hline Mean & & 6 & 4.6 & 76 & 0.282 & 1.26 & 0.299 \\
\hline
\end{tabular}

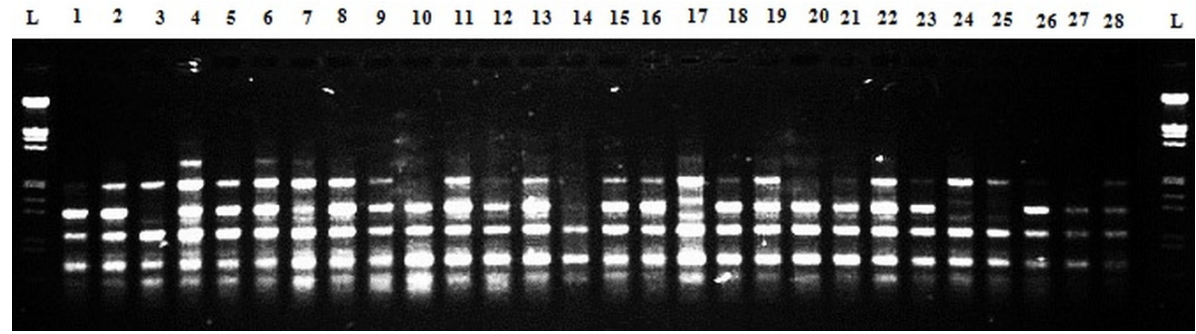

Fig. 3. Example of ISSR gel with ISSR-19 primer. The first twenty-eight cultivars represented in Tab. 1 are displayed from left to right. Ladders were run in the outside two lines 


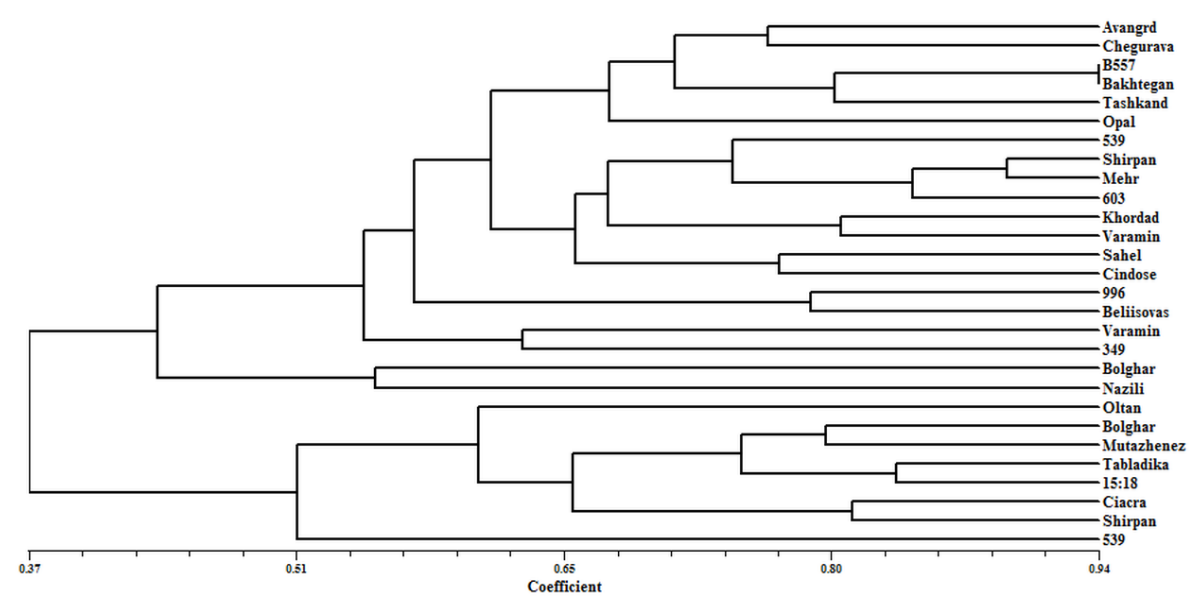

Fig. 4. Phenogram showing genetic diversity among 28 cotton cultivars using ISSR data

as variable function was performed to identify salinity associated markers with a high value of $\mathrm{R}^{2}$. In total 23 and 30 ISSR markers associated with measured agronomic traits in 2 salt treatments detected (Tab. 3 and 4).

At control salt treatment $(0 \mathrm{mM} \mathrm{NaCl})$, there was only one marker related to $\mathrm{K}^{+}$content whereas 8 markers were associated with $\mathrm{Na}^{+}$and $\mathrm{K}^{+} / \mathrm{Na}^{+}$. Positive markers related to $\mathrm{Na}^{+}$content and $\mathrm{K}^{+} / \mathrm{Na}^{+}$could explain $86 \%$ of variation (the highest) compare to $\mathrm{K}^{+}$and chlorophyll content related markers which was $28 \%$ (the lowest). ISSR14M4 was the most effective marker associated with studied agronomic traits at control salt treatment (Tab. 3).

Under severe salt stress $(140 \mathrm{mM})$ two markers were associated with $\mathrm{K}^{+} / \mathrm{Na}^{+}$and 8 markers were associated with root fresh weight. Markers in association with root fresh weight explained $91 \%$ of variation whereas amount of explained variance by $\mathrm{K}^{+} / \mathrm{Na}^{+}$associated was $40 \%$. At salt shock ISSR1M1 marker was the most effective marker associated with studied agronomic traits (Tab. 4).

Natural diversity provides a rich source of genetic recombination and mutations which can be analyzed for

Tab. 3. Regression coefficients and adjusted R square in the multiple regression between the agronomic triats and location ISSR gene in control

\begin{tabular}{|c|c|c|c|c|c|c|c|c|}
\hline & $\mathrm{RL}$ & RFW & RDW & chlorophyll & fluorescence & $\mathrm{Na}^{+}$ & $\mathrm{K}^{+}$ & $\mathrm{K}^{+} / \mathrm{Na}^{+}$ \\
\hline Intercept & 120.06 & 0.164 & 0.03 & 50.25 & 0.81 & 0.81 & 37.97 & 0.53 \\
\hline IS1M1 & 0.67 & & & & & -0.41 & & \\
\hline IS1M2 & & & & -0.64 & & & & \\
\hline IS1M4 & & & & & & & 0.53 & \\
\hline IS1M7 & & & 0.31 & & & & & \\
\hline IS1M8 & & & & & & -0.32 & & 0.80 \\
\hline IS2M1 & & & & & & & & -0.45 \\
\hline IS2M2 & & & & & & & & -0.30 \\
\hline IS3M2 & & & & & & -0.50 & & \\
\hline IS5M3 & & & & & & -0.41 & & \\
\hline IS8M2 & & 0.37 & & & & -0.31 & & \\
\hline IS9M1 & & & & & & & & -0.35 \\
\hline IS14M4 & & -0.62 & -0.53 & & & -0.50 & & \\
\hline IS14M5 & & & & & 0.86 & & & \\
\hline IS14M7 & -0.50 & & & & & & & \\
\hline IS15M1 & 0.26 & & & -0.32 & & & & \\
\hline IS16M1 & & & & & & & & -0.32 \\
\hline IS19M3 & & & & & & & & 0.60 \\
\hline IS19M4 & & & & & & & & -0.49 \\
\hline IS30M1 & & & 0.31 & & & 0.86 & & \\
\hline IS30M4 & -0.31 & & & & & 0.34 & & \\
\hline IS31M1 & & & & & & & & -0.27 \\
\hline IS31M3 & & & & & 0.53 & & & \\
\hline $\mathrm{R} 2$ & 0.73 & 0.41 & 0.50 & 0.28 & 0.62 & 0.86 & 0.28 & 0.86 \\
\hline
\end{tabular}


Tab. 4. Regression coefficients and adjusted $\mathrm{R}$ square in the multiple regression between the agronomic triats and location ISSR gene in $140 \mathrm{mM} \mathrm{NaCl}$ stress

\begin{tabular}{|c|c|c|c|c|c|c|c|c|}
\hline & $\mathrm{RL}$ & RFW & RDW & chlorophyll & fluorescence & $\mathrm{Na}^{+}$ & $\mathrm{K}^{+}$ & $\mathrm{K}^{+} / \mathrm{Na}^{+}$ \\
\hline Intercept & 87.48 & 0.05 & 0.05 & 42.93 & 0.79 & 46.13 & 32.45 & 1.12 \\
\hline IS1M1 & 0.44 & 0.43 & 0.64 & & & & & \\
\hline IS1M2 & & 0.39 & & & & & & \\
\hline IS1M3 & & & & & & & 0.40 & \\
\hline IS1M4 & & & -0.72 & & & & & \\
\hline IS1M7 & & & & -0.39 & & & & \\
\hline IS1M8 & & 0.30 & & & & -0.56 & & \\
\hline IS2M1 & & & -0.27 & 0.46 & & & & \\
\hline IS3M4 & -0.33 & & & & & & & \\
\hline IS5M7 & & -0.51 & & & & & & \\
\hline IS8M2 & & & & & & -0.48 & & \\
\hline IS8M4 & & 0.45 & & & & & & \\
\hline IS9M1 & 0.29 & & & & & & & \\
\hline IS9M4 & & & & & & 0.26 & & \\
\hline IS14M1 & & & & & 0.37 & & 0.34 & \\
\hline IS14M3 & 0.38 & & & & & & & \\
\hline IS14M4 & & -0.46 & & & & & & \\
\hline IS14M5 & & -0.22 & & & & & & \\
\hline IS14M6 & & & & & & -0.49 & & \\
\hline IS14M7 & & 0.20 & & & & & & \\
\hline IS15M1 & & & 0.38 & & & 0.33 & & \\
\hline IS15M3 & & & & 0.46 & & & & \\
\hline IS16M1 & & & & & -0.44 & & & \\
\hline IS16M2 & & & & & -0.47 & -0.78 & & \\
\hline IS19M6 & & & & & & & & -0.49 \\
\hline IS28M1 & & & -0.38 & & & & & \\
\hline IS30M3 & & & & & & & -0.56 & \\
\hline IS30M4 & & & & -0.41 & & & & \\
\hline IS30M5 & & & & & & -0.27 & & \\
\hline IS31M2 & & & & & 0.28 & & & 0.50 \\
\hline IS32M1 & & & & 0.59 & & & & \\
\hline R2 & 0.73 & 0.78 & 0.91 & 0.68 & 0.65 & 0.81 & 0.41 & 0.40 \\
\hline
\end{tabular}

salt tolerance (Galpaz and Reymond, 2010; Katori et al., 2010). DNA molecular markers are an important tool which can be incorporated in this kind of analysis. There is not enough marker data in cotton to screen cotton genotypes tolerant for salt stress.

\section{Conclusion}

The results showed that ISSR molecular marker could be served as useful method in breeding for salt tolerance in cotton but it could be used in future studies with more primers.

\section{Acknowledgment}

The authors appreciated Moghan agro-industry institute, for preparing the seed of studding cultivars.

\section{Referances}

Botstein D, White RL, Skolnick M, Davis RW (1980). Construction of a genetic linkage map in man using restriction fragment length polymorphisms. Am J Hum Genet 32:314331.

Darwish B, Poostini K, Tavakkol-Afshari R (2007). Ion Distribution Pattern in Various Alfalfa (Medicago sativa L.) Organs Respect to Phytomass under Saline Conditions. Iranian J Field Crops 40:31-43.

Doyle JJ, Doyle JL (1990). Isolation of plant DNA from fresh tissue. Focus 12:11-15.

FAO (2008). FAO statistical database.http://faostat.fao.org/ faostat/collections?subset=agriculture

Galpaz N, Reymond M (2010). Natural variation in Arabidopsis thaliana revealed a genetic network controlling germination under salt stress. PLoS One 5:e15198. 
126

Katori T, Ikeda A, Iuchi S, Kobayashi M, Shinozaki K, Maehashi K, Sakata Y, Tanaka S, Taji T (2010). Dissecting the genetic control of natural variation in salt tolerance of Arabidopsis thaliana accessions. J Exp Bot 61 (4):1125-1138.

Liedloff A (1999). MANTEL, Mantel nonparametric test calculator. Version 2.0.

Liu B, Wendel JF (2001). Intersimple sequence repeat (ISSR) polymorphisms as a genetic marker system in cotton. Molecular Ecology Notes 1:205-208.

Mateescu RG, Zhang Z, Tsai K, Phavaphutanon Burton-Wurster NI, Lust G, Quaas R, Murphy K, Acland GM, Todhunter RJ (2005). Analysis of allele fidelity polymorphic information content, and density of microsatellites in a genomewide screening for hip dysplasia in a crossbreed pedigree. Journal of Heredity 96(7):847-853.

Munns R, Schachtman DP, Condon AG (1995). The significance of two-phase growth response to salinityin wheat and barley. Australian Journal of Plant Physiology 22:561-569.
Nei M (1973). Analysis of gene diversity in subdivided populations. PNAS. 70:3321-3323.

Pradeep Reddy M, Sarla N, Siddiq EA (2002). Inter simple sequence repeat (ISSR) polymorphism and its application in plant breeding. Euphytica 128:9-17.

Preetha S, Raveendren TS (2008). Molecular marker technology in cotton. Biotechnology and Molecular Biology Review $3(2): 032-045$.

Qureshi Z. (2007). Surface water resources of st. johns river, Florida. J American Water Res Assoc 11(3):568-574.

Sharaf AN, El-kadi DA, Alatwani HF, Gamal El-Din AY, Abd El-Hadi AA (2009). Genetic Studies on Some Cotton Genotypes using DNA molecular markers. $4^{\text {th }}$ Conference on Recent Technologies in Agriculture 20:167-178.

Tanksley S, Nelson J (1996). Advanced backcross QTL analysis: a method for the simultaneous discovery and transfer of valuable QTLs from unadapted germplasm into elite breeding lines. Theor Appl Genet 92:191-203. 